\title{
Acylated 2-(N-arylaminomethylene)benzo[b]thiophene- 3(2H)-Ones: Molecular Switches with Varying Migrants and Substituents
}

\author{
Alexander D. Dubonosov, ${ }^{1}$ Vladimir P. Rybalkin, ${ }^{1}$ Lydia L. Popova, ${ }^{2}$ Alexey V. Tsukanov, ${ }^{1}$ \\ Yurii V. Revinsky, ${ }^{2}$ Vladimir A. Bren, ${ }^{2}$ and Vladimir I. Minkin ${ }^{1,2}$ \\ ${ }^{1}$ Southern Scientific Center of Russian Academy of Sciences, 344006 Rostov on Don, Russia \\ ${ }^{2}$ Institute of Physical and Organic Chemistry, Southern Federal University, 344090 Rostov on Don, Russia
}

Correspondence should be addressed to Alexander D. Dubonosov, aled@ipoc.rsu.ru

Received 9 February 2009; Revised 7 May 2009; Accepted 22 May 2009

Recommended by Mohamed Sabry Abdel-Mottaleb

Synthesis and properties of photochromic acylated 2-( $N$-arylaminomethylene)benzo[b]thiophene-3(2H)-ones are described. Their structure largely depends on the nature of acyl migrant and in a less degree on N-aryl substituent.

Copyright ( 2009 Alexander D. Dubonosov et al. This is an open access article distributed under the Creative Commons Attribution License, which permits unrestricted use, distribution, and reproduction in any medium, provided the original work is properly cited.

\section{Introduction}

2-(N-Acyl- $N$-arylaminomethylene)benzo $[b]$ thiophene$3(2 \mathrm{H})$-ones represent a new family of photochromic molecular switches with fluorescent signalling [1], chiroptical [2], and chemosensor activity [3-5]. They may also serve as $\mathrm{pH}$-sensors [6] and solar energy storage systems [7]. However the influence of the size and electronic properties of migrants and substituents in these compounds on their spectral, luminescent, and photochromic properties were insufficiently studied. To get a deeper insight into this problem we synthesized a series of novel $\mathrm{N}(\mathrm{O})$ acylated compounds (2)-(8) and studied their structure, spectral properties, and quantum yields of the $\mathrm{N} \rightarrow \mathrm{O}$ acyl rearrangements.

\section{Experimental}

${ }^{1} \mathrm{H}$ NMR spectra were recorded on a Varian Unity 300 spectrometer; $\delta$ values were measured within $0.01 \mathrm{ppm}$. IR spectra in Nujol were measured using a Specord 75IR spectrometer. UV-Vis absorption spectra in toluene were obtained with a Specord M-40 spectrophotometer. Fluorescence emission and excitation spectra were recorded on a Hitachi 650-60 spectrofluorimeter. Irradiation of solutions
$\left(V=2 \cdot 10^{-3} \mathrm{~L}\right)$ was carried out by filtered light of a highpressure mercury lamp DRSh $(250 \mathrm{~W})$ supplied with a set of glass filters $\left(\lambda_{\text {irr }}=436 \mathrm{~nm}\right)$. The intensity of light used for irradiation of the solutions was $3 \cdot 10^{16}$ photons $^{-1}{ }^{-1}$ for the spectral line $436 \mathrm{~nm}$. Potassium ferrioxalate was used as the actinometer for the determination of quantum yields $(\varphi)$ of the photoreactions [8]. The samples had absorbance of 0.95 at $\lambda_{\text {irr }}=436 \mathrm{~nm}\left(l=1 \mathrm{~cm}, V=2 \cdot 10^{-3} \mathrm{~L}\right.$, rate of conversion of $\mathrm{A} \rightarrow \mathrm{B} \leq 5 \%$, the experimental error in $\varphi$ is $\pm 5 \%$ ).

\section{Results and Discussion}

3.1. Synthesis. Compounds (2), (3a), (3b), (4a), (4b), (5), and (6) were synthesized according to the previously described procedure [9] (Scheme 1). Compound (4c) was synthesized according to procedure [7].

All the compounds obtained were divided into four groups according to the electronic and steric properties of acyl migrants and $\mathrm{N}$-aryl substituents. The first group of acylated 2-( $\mathrm{N}$-arylaminomethylene)benzo[b] thiophene$3(2 \mathrm{H})$-ones consists of the compounds with the gradually increased bulkiness of the migrant: $\mathrm{R}^{1}=\mathrm{H}(2)$, Me (3a), Et (3b), $\operatorname{Pr}^{i}(4 a), B^{t}(5)$. The second one includes acylated ketoenamines possessing migrants with increasing 
electron-donating properties of $\alpha$-C substituents: $\mathrm{R}^{1}=\mathrm{H}(2)$, $\mathrm{Ph}$ (4c), $\mathrm{Me}$ (3a), OMe (4b), $\mathrm{NMe}_{2}$ (6).

The third series represents compounds with varying 4substituents in the aroyl migrant: $\mathrm{R}^{3}=\mathrm{H}(4 \mathrm{c}), 4-\mathrm{MeO}(7 \mathrm{a})$, 4$\mathrm{Cl}(7 \mathrm{~b}), 4-\mathrm{NO}_{2}$ (7c). In the fourth group we united molecules with varying 4-substituent in N-Ar part of the molecule: $\mathrm{R}^{2}$ $=\mathrm{NMe}_{2}$ (8a), OMe (8b), Me (8c), I (8d), Br (8e), Cl (8f), F $(8 \mathrm{~g}), \mathrm{CN}(8 \mathrm{~h}), \mathrm{COMe}(8 \mathrm{i}), \mathrm{NO}_{2}(8 \mathrm{j})$. Their synthesis is shown on Scheme 2.

2-(N-aroyl-N-phenylaminomethylene)benzo[b] thiophe-ne$3(2 \mathrm{H})$-ones $(7 a)-(7 c)$ (general procedure). 2-(N-phenylaminomethylene)benzo[ $b]$ thiophene-3(2H)-one (1a) (1 mmol) was dissolved in $3 \mathrm{~mL}$ of acetonitrile in the presence of triethylamine and a solution of $1.2 \mathrm{mmol}$ of corresponding aroyl chloride in $2 \mathrm{~mL}$ of acetonitrile was added at room temperature. The mixture was refluxed for 3-5 minutes. The precipitate was filtered and crystallized from toluene.

(i) 2-(N-4-methoxybenzoyl-N-phenylaminomethylene)benzo[b] thiophene-3(2H)-one (7a). (31\%); mp $177-179^{\circ} \mathrm{C}$; IR $\left(v_{\text {max }} / \mathrm{cm}^{-1}\right.$, nujol): 1660, 1640, 1590, 1580, $1550 ;{ }^{1} \mathrm{H}$ $\mathrm{NMR}\left(300 \mathrm{MHz}, \mathrm{CDCl}_{3}\right): \delta 3.81\left(3 \mathrm{H}, \mathrm{s}, \mathrm{CH}_{3}\right), 6.80-7.84$ $(13 \mathrm{H}, \mathrm{m}, \mathrm{Ar}-\mathrm{H}), 8.67(1 \mathrm{H}, \mathrm{s},=\mathrm{CH})$; Anal. Calcd for $\mathrm{C}_{23} \mathrm{H}_{17} \mathrm{NO}_{3} \mathrm{~S}$ : C, 71.30; H, 4.42; N, 3.61; Found: C, 71.19; H, $4.52 ; \mathrm{N}, 3.73$.

(ii) 2-(N-4-chlorobenzoyl-N-phenylaminomethylene)benzo[b] thiophene-3(2H)-one (7b). (64\%); mp 215-216 $\mathrm{C}$; IR $\left(v_{\max } / \mathrm{cm}^{-1}\right.$, nujol): 1640, 1580, $1560 ;{ }^{1} \mathrm{H} \mathrm{NMR}(300 \mathrm{MHz}$, $\left.\mathrm{CDCl}_{3}\right): \delta 7.16-7.85(13 \mathrm{H}, \mathrm{m}, \mathrm{Ar}-\mathrm{H}), 8.67(1 \mathrm{H}, \mathrm{s},=\mathrm{CH})$; Anal. Calcd for $\mathrm{C}_{22} \mathrm{H}_{14} \mathrm{ClNO}_{2} \mathrm{~S}$ : C, 67.43; H, 3.60; N, 3.57; Found: C, 67.50; H, 6.73; N, 3.41.

(iii) 2-(N-4-nitrobenzoyl-N-phenylaminomethylene)benzo[b]thiophene-3(2H)-one (7c). (57\%); mp 211-212 ${ }^{\circ} \mathrm{C}$; IR $\left(v_{\max } / \mathrm{cm}^{-1}\right.$, nujol): $1690,1680,1600,1580,1560,1520 ;{ }^{1} \mathrm{H}$ NMR (300 MHz, $\left.\mathrm{CDCl}_{3}\right): \delta 7.18-8.17(13 \mathrm{H}, \mathrm{m}, \mathrm{Ar}-\mathrm{H}), 8.74$ $(1 \mathrm{H}, \mathrm{s},=\mathrm{CH})$; Anal. Calcd for $\mathrm{C}_{22} \mathrm{H}_{14} \mathrm{~N}_{2} \mathrm{O}_{4} \mathrm{~S}$ : C, 65.66; $\mathrm{H}$, 3.51; N, 6.96; Found: C, 65.60; H, 3.66; N, 6.84.

(iv) 2-(N-acetyl-N-arylaminomethylene)benzo $[b]$ thiophene-3(2H)-ones (8a)-(8j) (general procedure). Corresponding 2-(N-arylaminomethylene)benzo $[b]$ thiophene$3(2 \mathrm{H})$-ones (1b)- $(1 \mathrm{n})$ [10] (1 mmol) were dissolved in acetic anhydride $(2 \mathrm{~mL})$ in the presence of triethylamine and refluxed for 5-10 minutes. The precipitate was filtered and crystallized from toluene.

(v) 2-\{N-acetyl-N-(4-N,N-dimethylaminophenyl)aminomethylene benzo[b]thiophene-3(2H)-one (8a). (77\%); mp $245-246^{\circ} \mathrm{C}$; IR $\left(v_{\max } / \mathrm{cm}^{-1}\right.$, nujol): $1690,1640,1590,1550$, $1510 ;{ }^{1} \mathrm{H}$ NMR $\left(300 \mathrm{MHz}, \mathrm{CDCl}_{3}\right): \delta 2.03\left(3 \mathrm{H}, \mathrm{s}, \mathrm{CH}_{3}\right), 3.08$ $\left(6 \mathrm{H}, \mathrm{s}, \mathrm{N}\left(\mathrm{CH}_{3}\right)_{2}\right), 6.77-7.82(8 \mathrm{H}, \mathrm{m}, \mathrm{Ar}-\mathrm{H}), 8.98(1 \mathrm{H}, \mathrm{s}$, $=\mathrm{CH})$; Anal. Calcd for $\mathrm{C}_{19} \mathrm{H}_{18} \mathrm{~N}_{2} \mathrm{O}_{2} \mathrm{~S}$ : C, 67.43; H, 5.36; N, 8.28; Found: C, 67.56; H, 5.28; N, 8.20.

(vi) 2-\{N-acetyl-N-(4-methoxyphenyl)aminomethylene $\}$ benzo[b]thiophene-3(2H)-one (8b). (43\%); mp 193-194 ${ }^{\circ} \mathrm{C}$; IR $\left(v_{\text {max }} / \mathrm{cm}^{-1}\right.$, nujol): $1690,1660,1570,1540 ;{ }^{1} \mathrm{H}$ NMR $\left(300 \mathrm{MHz}_{\mathrm{CDCl}}\right): \delta 2.08\left(3 \mathrm{H}, \mathrm{s}, \mathrm{CH}_{3}\right), 3.94\left(3 \mathrm{H}, \mathrm{s}, \mathrm{OCH}_{3}\right)$, 7.02-7.83 (8H, m, Ar-H), $8.92(1 \mathrm{H}, \mathrm{s},=\mathrm{CH})$; Anal. Calcd for $\mathrm{C}_{18} \mathrm{H}_{15} \mathrm{NO}_{3} \mathrm{~S}$ : C, 66.44; H, 4.65; N, 4.30; Found: C, 66.59; H, $4.66 ; \mathrm{N}, 4.18$. (vii) 2-\{N-acetyl-N-(4-methylphenyl)aminomethylene $\}$ benzo[b]thiophene-3(2H)-one (8c). (83\%); mp $210-212^{\circ} \mathrm{C}$; IR $\left(v_{\max } / \mathrm{cm}^{-1}\right.$, nujol): 1700, 1650, 1580, 1550; ${ }^{1} \mathrm{H}$ NMR $\left(300 \mathrm{MHz}, \mathrm{CDCl}_{3}\right): \delta 2.05\left(3 \mathrm{H}, \mathrm{s}, \mathrm{COCH}_{3}\right), 2.52(3 \mathrm{H}, \mathrm{s}$, $\left.\mathrm{CH}_{3}\right), 7.15-7.82(8 \mathrm{H}, \mathrm{m}, \mathrm{Ar}-\mathrm{H}), 8.95(1 \mathrm{H}, \mathrm{s},=\mathrm{CH})$; Anal. Calcd for $\mathrm{C}_{18} \mathrm{H}_{15} \mathrm{NO}_{2} \mathrm{~S}$ : C, 69.88; H, 4.89; N, 4.53; Found: C, 69.87; H, 4.74; N, 4.65.

(viii) 2-\{N-acetyl-N-(4-iodophenyl)aminomethylene $\}$ benzo[b]thiophene-3(2H)-one (8d). (73\%); mp 241-243 ${ }^{\circ} \mathrm{C}$; IR $\left(v_{\max } / \mathrm{cm}^{-1}\right.$, nujol): $1700,1660,1590,1550 ;{ }^{1} \mathrm{H}$ NMR $\left(300 \mathrm{MHz} \mathrm{CDCl}_{3}\right): \delta 2.11\left(3 \mathrm{H}, \mathrm{s}, \mathrm{CH}_{3}\right), 7.03-7.94(8 \mathrm{H}, \mathrm{m}$, Ar-H), $8.82(1 \mathrm{H}, \mathrm{s},=\mathrm{CH})$; Anal. Calcd for $\mathrm{C}_{17} \mathrm{H}_{12} \mathrm{INO}_{2} \mathrm{~S}: \mathrm{C}$, 48.47; H, 2.87; N, 3.32; Found: C, 48.38; H, 2.90; N, 3.32.

(ix) 2-\{N-acetyl-N-(4-bromophenyl)aminomethylene $\}$ benzo[b]thiophene-3(2H)-one (8e). (85\%); mp 218-219 ${ }^{\circ} \mathrm{C}$; IR $\left(v_{\max } / \mathrm{cm}^{-1}\right.$, nujol): 1700, 1660, 1590, 1560, 1550; ${ }^{1} \mathrm{H}$ NMR $\left(300 \mathrm{MHz}, \mathrm{CDCl}_{3}\right): \delta 2.12\left(3 \mathrm{H}, \mathrm{s}, \mathrm{CH}_{3}\right), 7.19-$ $7.83(8 \mathrm{H}, \mathrm{m}, \mathrm{Ar}-\mathrm{H}), 8.82(1 \mathrm{H}, \mathrm{s},=\mathrm{CH})$; Anal. Calcd for $\mathrm{C}_{17} \mathrm{H}_{12} \mathrm{BrNO}_{2} \mathrm{~S}$ : C, 54.56; H, 3.23; N, 3.74; Found: C, 54.68; $\mathrm{H}, 3.17$; N, 3.63 .

(x) 2-\{N-acetyl-N-(4-chlorophenyl)aminomethylene $\}$ benzo[b]thiophene-3(2H)-one (8f). (70\%); mp $186-187^{\circ} \mathrm{C}$; IR $\left(v_{\max } / \mathrm{cm}^{-1}\right.$, nujol): $1700,1660,1590,1550 ;{ }^{1} \mathrm{H} \mathrm{NMR}$ $\left(300 \mathrm{MHz} \mathrm{CDCl}_{3}\right): \delta 2.10\left(3 \mathrm{H}, \mathrm{s}, \mathrm{CH}_{3}\right), 7.19-7.84(8 \mathrm{H}, \mathrm{m}$, Ar-H), $8.83(1 \mathrm{H}, \mathrm{s},=\mathrm{CH})$; Anal. Calcd for $\mathrm{C}_{17} \mathrm{H}_{12} \mathrm{ClNO}_{2} \mathrm{~S}$ : C, 61.91; H, 3.67; N, 4.25; Found: C, 62.03; H, 3.60; N, 4.27.

(xi) 2-\{N-acetyl-N-(4-fluorophenyl)aminomethylene $\}$ benzo[b] thiophene-3(2H)-one (8g). (69\%); mp 213-214 ${ }^{\circ} \mathrm{C}$; IR $\left(v_{\text {max }} / \mathrm{cm}^{-1}\right.$, nujol): $1700,1660,1590,1580,1540 ;{ }^{1} \mathrm{H}$ $\mathrm{NMR}\left(300 \mathrm{MHz}, \mathrm{CDCl}_{3}\right): \delta 2.10\left(3 \mathrm{H}, \mathrm{s}, \mathrm{CH}_{3}\right), 7.20-7.84(8 \mathrm{H}$, $\mathrm{m}, \mathrm{Ar}-\mathrm{H}), 8.84(1 \mathrm{H}, \mathrm{s},=\mathrm{CH})$; Anal. Calcd for $\mathrm{C}_{17} \mathrm{H}_{12} \mathrm{FNO}_{2} \mathrm{~S}$ : C, 65.16; H, 3.86; N, 4.47; Found: C, 65.15; H, 3.95; N, 4.40.

(xii) 2-\{N-acetyl-N-(4-cyanophenyl)aminomethylene $\}-$ benzo[b] thiophene-3(2H)-one (8h). (57\%); mp $215-216^{\circ} \mathrm{C}$; IR $\left(v_{\max } / \mathrm{cm}^{-1}\right.$, nujol): $1690,1670,1580,1560 ;{ }^{1} \mathrm{H}$ NMR $\left(300 \mathrm{MHz}, \mathrm{CDCl}_{3}\right): \delta 2.21\left(3 \mathrm{H}, \mathrm{s}, \mathrm{CH}_{3}\right), 7.20-7.90(8 \mathrm{H}, \mathrm{m}$, Ar-H), 8.73 (1H, s, =CH); Anal. Calcd for $\mathrm{C}_{18} \mathrm{H}_{12} \mathrm{~N}_{2} \mathrm{O}_{2} \mathrm{~S}: \mathrm{C}$, 67.48; H, 3.78; N, 8.74; Found: C, 67.54; H, 3.87; N, 8.62.

(xiii) 2-\{N-acetyl-N-(4-acetylphenyl)aminomethylene $\}-$ benzo[b]thiophene-3(2H)-one (8i). (48\%); mp $186-187^{\circ} \mathrm{C}$; IR $\left(v_{\max } / \mathrm{cm}^{-1}\right.$, nujol): 1695, 1670, 1660, 1595, 1570, 1550; ${ }^{1} \mathrm{H} \mathrm{NMR}\left(300 \mathrm{MHz}^{\mathrm{CDCl}} \mathrm{CDC}_{3}\right): \delta 2.16\left(3 \mathrm{H}, \mathrm{s}, \mathrm{NCOCH}_{3}\right), 2.74$ $\left(3 \mathrm{H}, \mathrm{s}, \mathrm{COCH}_{3}\right), 7.15-8.18(8 \mathrm{H}, \mathrm{m}, \mathrm{Ar}-\mathrm{H}), 8.82(1 \mathrm{H}, \mathrm{s}$, $=\mathrm{CH})$; Anal. Calcd for $\mathrm{C}_{19} \mathrm{H}_{15} \mathrm{NO}_{3} \mathrm{~S}: \mathrm{C}, 67.64 ; \mathrm{H}, 4.48 ; \mathrm{N}$, 4.15; Found: C, 67.69; H, 4.38; N, 4.22.

(xiv) 2-\{N-acetyl-N-(4-nitrophenyl)aminomethylene $\}$ benzo[b]thiophene-3(2H)-one (8j). (37\%); mp 199-200 ${ }^{\circ} \mathrm{C}$; IR $\left(v_{\max } / \mathrm{cm}^{-1}\right.$, nujol): 1700, 1670, 1600, 1580, 1560, 1530; ${ }^{1} \mathrm{H}$ NMR $\left(300 \mathrm{MHz}, \mathrm{CDCl}_{3}\right): \delta 2.22\left(3 \mathrm{H}, \mathrm{s}, \mathrm{CH}_{3}\right), 7.19-$ $8.47(8 \mathrm{H}, \mathrm{m}, \mathrm{Ar}-\mathrm{H}), 8.74(1 \mathrm{H}, \mathrm{s},=\mathrm{CH})$; Anal. Calcd for $\mathrm{C}_{17} \mathrm{H}_{12} \mathrm{~N}_{2} \mathrm{O}_{4} \mathrm{~S}$ : C, 59.99; H, 3.55; N, 8.23; Found: C, 59.86; $\mathrm{H}, 3.63$; N, 8.23.

3.2. Photochromic Properties. According to the performed IR and NMR spectral study compounds (2)-(4), (7), and (8) exist in solutions as the $\mathrm{N}$-acylated isomers. Their IR-spectra contain absorption bands of the amide $\left(1660-1730 \mathrm{~cm}^{-1}\right)$ 


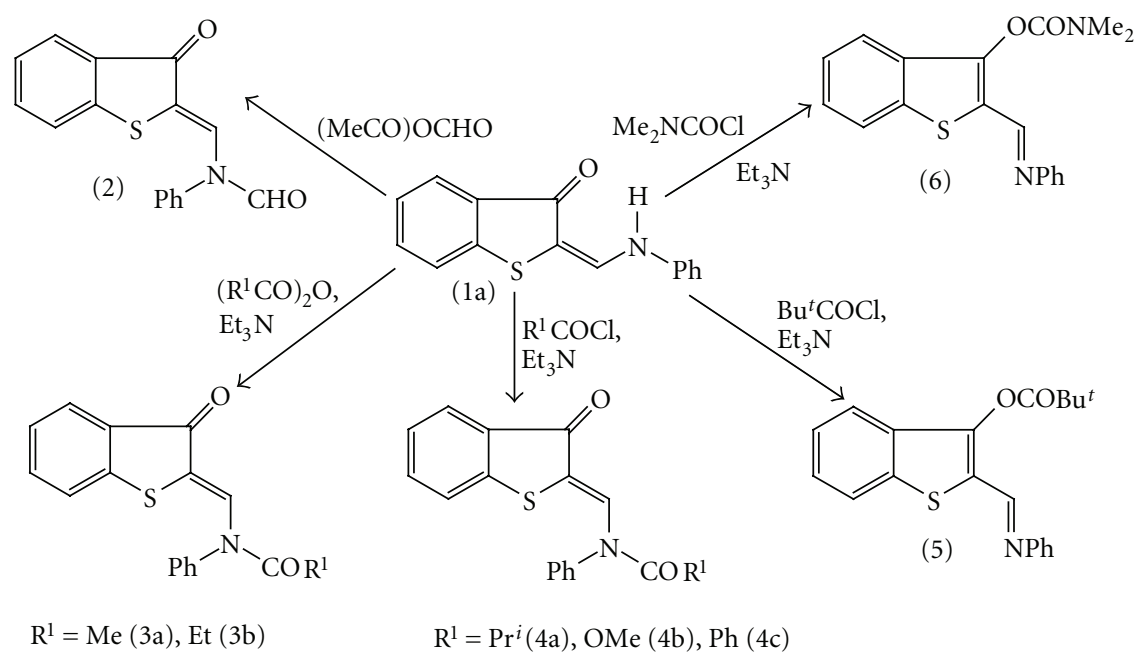

Scheme 1

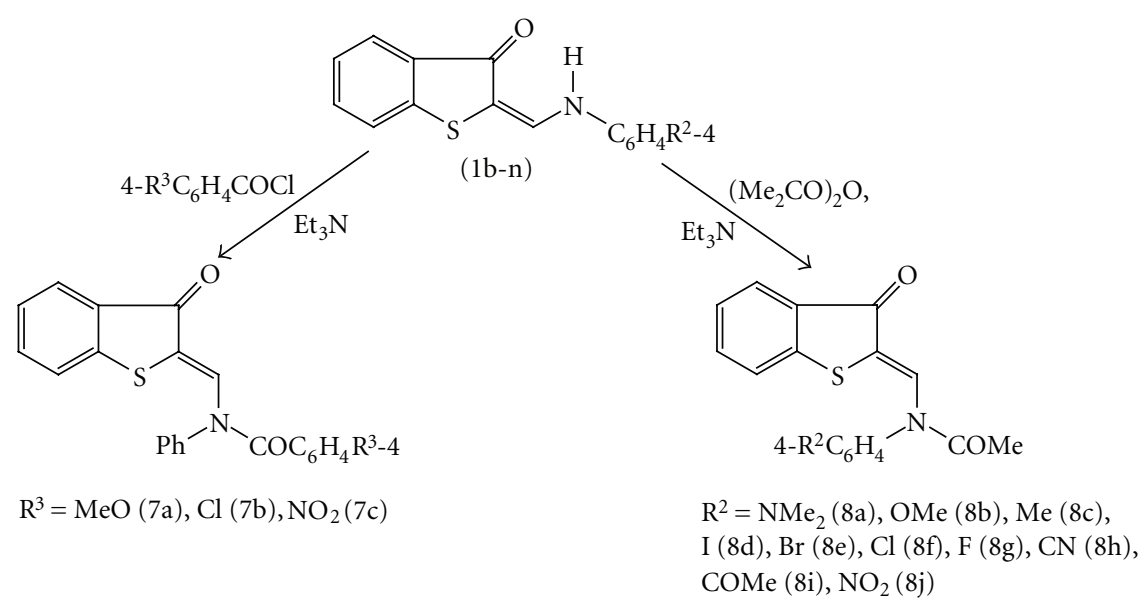

Scheme 2

and exocyclic carbonyl groups $\left(1660-1680 \mathrm{~cm}^{-1}\right) .{ }^{1} \mathrm{H}$ NMR spectra consist of characteristic signals of methine protons at 8.70-9.00 ppm which correspond to the initial $Z$ configuration [3]. N-Acylated ketoenamines (2)-(4), (7), and (8) absorb in 420-430 $\mathrm{nm}$ spectral region (Table 1). On the contrary, compounds (5), (6) correspond to Oacyl derivatives. They possess typical absorption in the UV spectral region (338-342 nm) [9] and their IR spectra contain ester carbonyl group signals $\left(1720-1750 \mathrm{~cm}^{-1}\right)$.

For the majority of $\mathrm{N}$-acylated forms A of compounds (3), (4), (7), (8) irradiation $\left(\lambda_{\text {irr }}=436 \mathrm{~nm}\right)$ of toluene solutions results in $Z \rightarrow E$-photoisomerization around the $\mathrm{C}=\mathrm{C}$ bond followed by a fast thermal $\mathrm{N} \rightarrow \mathrm{O}$ acyl migration and $S$-cis $\rightarrow S$-trans isomerization of $\mathrm{O}$-acyl compounds $\mathrm{B}$ (Scheme 3, Figure 1). Quantum yields $(\varphi)$ of the $A \rightarrow B$ photorearrangement include all stages shown on Scheme 3 from $Z$-A to $S$-trans-B though we consider all thermal rearrangements to be very rapid [7]. These summarized quantum yields are given in Table 1.
In the series of compounds with varying migrant volume, the smallest migrant $\mathrm{CHO}$ (2) inhibits $\mathrm{A} \rightarrow \mathrm{B}$ photorearrangement and restricts it by the thermally reversible $Z \rightarrow E$ photoisomerization. The specific feature of this process is the formation of photostationary state depending on the wavelength of irradiation light (Figure 2). N-Acyl derivatives (3a), (3b), and (4a) reveal typical photochromic behavior (Scheme 3). The compound with the most bulky $\mathrm{Bu}^{t}$ (5) substituent exists in the thermodinamically stable O-form B. Its photoinitiated reactions are limited by thermally reversible anti-syn isomerization around $\mathrm{C}=\mathrm{N}$ bond.

The representatives of second group (2), (3a), (4b), (4c) with varying electronic migrant exist in $\mathrm{N}$-acyl form $\mathrm{A}$ and demonstrate $\mathrm{N} \rightarrow \mathrm{O}$ acyl rearrangement in accordance with Scheme 3 (except above described ketoenamine 2). The compound with the strong electron-donating $\alpha$-C substituent $\mathrm{NMe}_{2}$ (6) occurs in the form of $\mathrm{O}$-acyl isomer $\mathrm{B}$ and shows only anti-syn isomerization around the $\mathrm{C}=\mathrm{N}$ bond, similar to (5). 

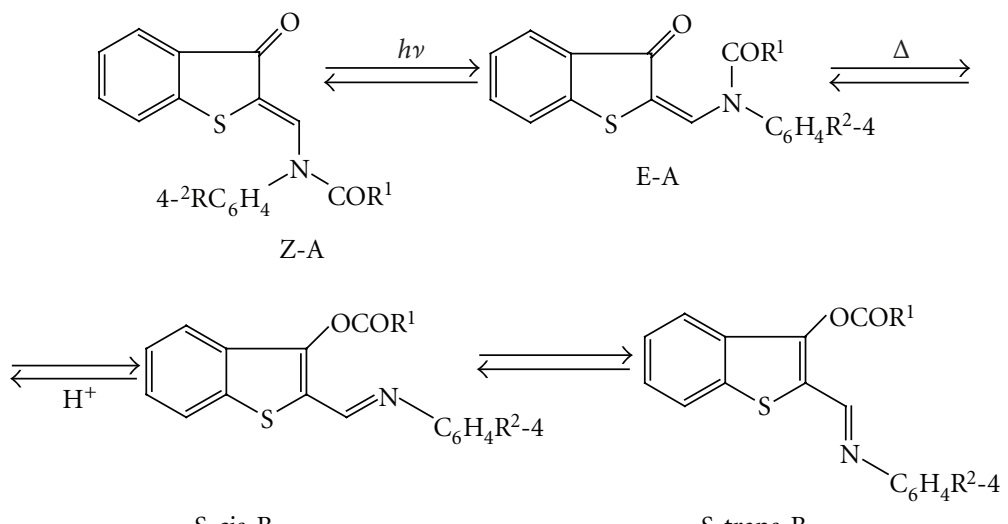

S-cis-B

S-trans-B

Scheme 3

TABle 1: Spectral characteristics (long-wave length maxima) of (2)-(8) in acetonitrile solutions and quantum yields $(\varphi)$ of the $A \rightarrow B$ rearrangement.

\begin{tabular}{|c|c|c|c|}
\hline Comp. & $\begin{array}{l}\text { Absorption of }(Z-\mathrm{A}), \lambda_{\max }(\mathrm{nm}) \text {, } \\
\quad\left(\varepsilon \times 10^{-4}, \mathrm{dm}^{3} \mathrm{~mol}^{-1} \mathrm{~cm}^{-1}\right)\end{array}$ & $\varphi_{\mathrm{A} \rightarrow \mathrm{B}}$ & $\begin{array}{l}\text { Absorption of }(S \text {-trans-B }), \lambda_{\max }(\mathrm{nm}), \\
\quad\left(\varepsilon \times 10^{-4}, \mathrm{dm}^{3} \mathrm{~mol}^{-1} \mathrm{~cm}^{-1}\right)\end{array}$ \\
\hline $2^{*}$ & $424(1.10)$ & - & - \\
\hline $3 a^{*}$ & $427(1.04)$ & 0.60 & $338(2.32)$ \\
\hline $3 b$ & $425(1.24)$ & 0.63 & $339(2.27)$ \\
\hline $4 \mathrm{a}$ & $427(1.28)$ & 0.62 & $342(2.24)$ \\
\hline $4 b^{*}$ & $422(1.17)$ & 0.41 & $333(0.81)$ \\
\hline $4 c^{*}$ & $423(1.36)$ & 0.52 & $340(2.14)$ \\
\hline $7 \mathrm{a}$ & $430(1.42)$ & 0.48 & $342(2.19)$ \\
\hline $7 \mathrm{~b}$ & $430(1.32)$ & 0.40 & $343(2.09)$ \\
\hline $7 \mathrm{c}$ & $431(1.34)$ & 0.002 & - \\
\hline $8 \mathrm{a}$ & $430(1.41)$ & - & - \\
\hline $8 b$ & $425(1.22)$ & 0.50 & $353(2.20)$ \\
\hline $8 c$ & $425(1.26)$ & 0.50 & $345(2.25)$ \\
\hline $8 \mathrm{~d}$ & $425(1.23)$ & 0.47 & $350(2.56)$ \\
\hline $8 \mathrm{e}$ & $424(1.22)$ & 0.51 & $347(2.51)$ \\
\hline $8 \mathrm{f}$ & $424(1.23)$ & 0.49 & $347(2.51)$ \\
\hline $8 g$ & $424(1.19)$ & 0.41 & $342(2.30)$ \\
\hline $8 \mathrm{~h}$ & $424(1.13)$ & 0.48 & $346(2.52)$ \\
\hline $8 \mathrm{i}$ & $424(1.29)$ & 0.45 & $350(2.74)$ \\
\hline $8 \mathrm{j}$ & $424(1.14)$ & 0.29 & $356(2.65)$ \\
\hline 5 & - & - & $338(2.36)$ \\
\hline 6 & - & - & $342(2.14)$ \\
\hline
\end{tabular}

Varying of 4-substituent in aroyl group (7a)-(7c) results in decrease of quantum yield $\mathrm{A} \rightarrow \mathrm{B}$ rearrangement almost up to zero (Table 1) as correlated with the increase of electronwithdrawing properties of $\mathrm{R}^{3}$.

In the fourth series the substituents in the position 4 of the $\mathrm{N}$-Ar moiety of the compounds $(8 \mathrm{~b})-(8 \mathrm{j})$ only slightly affect the character of the photochromic $\mathrm{A} \rightarrow \mathrm{B}$ photorearrangement (Table 1). The photochemical transformations of (8a) with $\mathrm{NMe}_{2}$ substituent lead to formation of a mixture of $\mathrm{O}$ - and $\mathrm{N}$-isomers with predominance of the last one due to overlap of long-wavelength absorption bands of initial compound and photoproduct.

In toluene solutions, at $293 \mathrm{~K}, \mathrm{~N}$-acylated compounds (2)-(4), (7), and (8) exhibit weak fluorescence with maxima at $460-470 \mathrm{~nm}$ which extinguishes after the rearrangement into the O-acetyl isomers B due to the fast intersystem crossing processes ("on-off" process) [9]. The B $\rightarrow$ A back reaction occuring when passing dried hydrogen chloride 


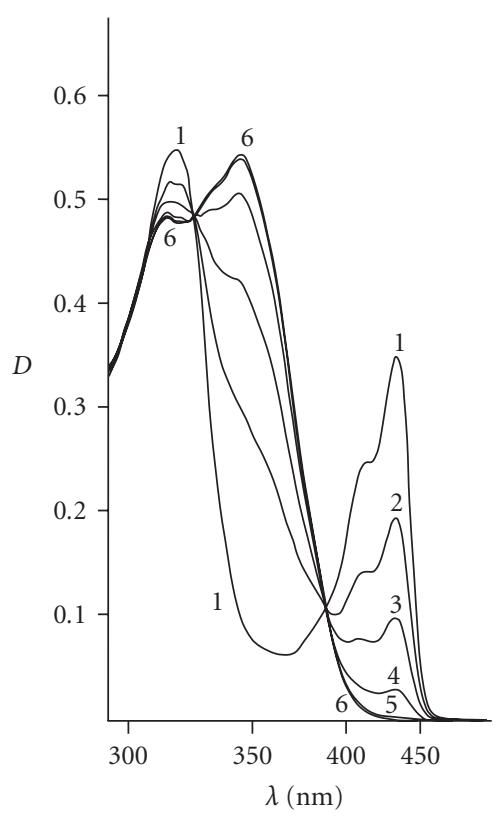

Figure 1: Absorption spectra of (8b) in toluene solution before irradiation (1); after 5 seconds (2); 10 seconds (3); 20 seconds (4); 40 seconds $(5) ; 120$ seconds $(6)$ of irradiation $\left(\lambda_{\text {irr }}=436 \mathrm{~nm}, C=\right.$ $\left.2.5 \cdot 10^{-5} \mathrm{M}\right)$.

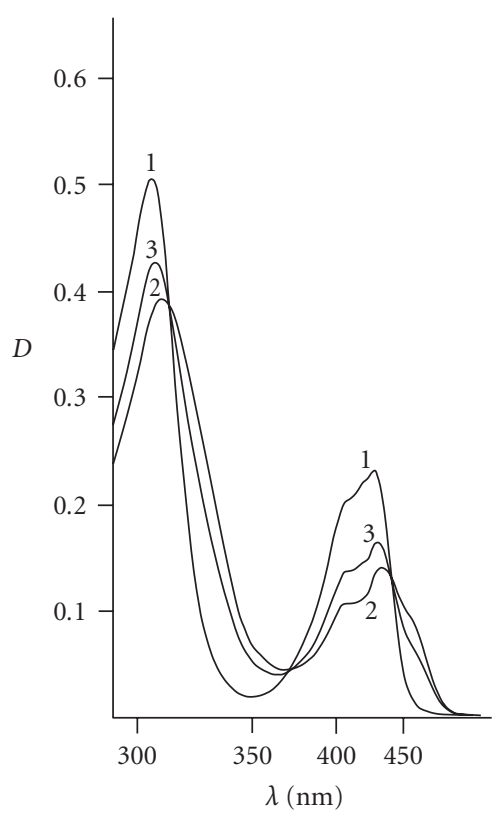

Figure 2: Absorption spectra of (1a) in toluene solution before irradiation (1); after 120 seconds (2) of irradiation $\left(\lambda_{\text {irr }}=365 \mathrm{~nm}\right)$ and after 120 seconds ( 3$)$ of irradiation $\left(\lambda_{\text {irr }}=436 \mathrm{~nm}\right) ; \mathrm{C}=2.5 \cdot 10^{-5}$ M.

through a toluene solution of form B results in complete restoration of the initial absorption and emission spectra of form A ("off-on"process).

\section{Conclusions}

Series of $\mathrm{N}(\mathrm{O})$-acylated 2-(N-arylaminomethylene)benzo[b]thiophene-3(2H)- ones with varying electronic and steric properties of substituents in the acyl migrants and $\mathrm{N}$-aryl groups were prepared. By means of electronic absorption, vibrational, and ${ }^{1} \mathrm{H}$ NMR spectroscopy, it was shown that ketoenamine with the smallest formyl substituent undergoes only reversible $Z \rightarrow E$ photoisomerization. The compounds containing the strongest electron-donating $\left(\mathrm{NMe}_{2}\right)$ and the most bulky $\left(\mathrm{Bu}^{t}\right)$ substituents in acyl migrants represent the thermodynamically stable $\mathrm{O}$-isomers. Their irradiation results only in the thermally reversible anti-syn isomerization around the $\mathrm{C}=\mathrm{N}$ bond. The other compounds exhibit negative photochromism $\left(\lambda_{\max } \mathrm{B}<\right.$ $\left.\lambda_{\max } \mathrm{A}\right)$ based on photoinduced $Z \rightarrow E$ photoisomerization followed by the thermal $\mathrm{N} \rightarrow \mathrm{O}$ transfer of the acyl group.

\section{Acknowledgments}

This work was supported by Russian Foundation for Basic Research (Grants N 06-03-32561, 09-03-00052), RF Ministry of Education and Science (Grants RNP.16012 and RNP.2348) and President's of RF Grant (NSh-363.2008.3).

\section{References}

[1] V. A. Bren, A. D. Dubonosov, O. G. Karamov, et al., "2-[N-acetyl- $N$-(2-fluorenonyl)aminomethylene $]$ benzo $[b]-$ thiophen-3(2H)-one, a molecular fluorescent switch," Russian Journal of Organic Chemistry, vol. 38, no. 11, pp. 1698-1699, 2002.

[2] V. P. Rybalkin, J. Y. Vorob’eva, G. S. Borodkin, et al., "Synthesis and properties of photoacylotropic (2Z)-2-(N-acyl- $N$ arylaminomethylidene)benzo $[b]$ thiophen-3(2H)-ones with a chiral migrating group," Russian Chemical Bulletin, vol. 54, no. 12, pp. 2783-2789, 2005.

[3] V. A. Bren, A. D. Dubonosov, V. I. Minkin, et al., "Photochromic crown-containing molecular switches of chemosensor activity," Journal of Physical Organic Chemistry, vol. 20, no. 11, pp. 917-928, 2007.

[4] V. A. Bren, A. D. Dubonosov, V. I. Minkin, et al., "Photochromic cation sensors," Molecular Crystals and Liquid Crystals, vol. 431, pp. 417-422, 2005.

[5] A. D. Dubonosov, V. I. Minkin, V. A. Bren, et al., "Photochromic 2-(N-acyl- $N$-arylaminomethylene)benzo[b] thiophene-3(2H)-oneswith fluorescent labels and/or crownether receptors," Archive for Organic Chemistry, vol. 2003, no. 13, pp. 12-20, 2003.

[6] V. A. Bren, A. D. Dubonosov, V. I. Minkin, et al., "Molecular switching and PET effect in the molecules of 2-(9anthrylmethylaminomethylene) benzo $[b]$ thiophene and its $N$ acetyl derivative," Russian Journal of Organic Chemistry, vol. 38, no. 12, pp. 1813-1814, 2002.

[7] V. I. Minkin, V. A. Bren, and A. E. Lyubarskaya, Organic Photochromes, Consultants Bureau, New York, NY, USA, 1990.

[8] C. A. Parker, Photoluminescence of Solutions, Elsevier, Amsterdam, The Netherlands, 1968. 
[9] V. P. Rybalkin, L. L. Popova, A. V. Tsukanov, A. D. Dubonosov, V. A. Bren, and V. I. Minkin, "N(O)-acylated 2-(Nphenylaminomethylene)benzo $[b]$ thiophene-3(2H)-ones as molecular switches with a variable migrant," High Energy Chemistry, vol. 42, no. 7, pp. 606-609, 2008.

[10] V. A. Bren, V. I. Usacheva, and V. I. Minkin, "Benzenoidquinonoid tautomerism of azomethines and their structural analogs," Chemistry of Heterocyclic Compounds, vol. 8, no. 7, pp. 836-840, 1974. 


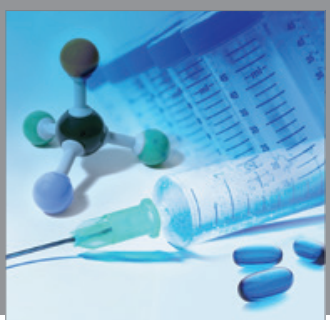

International Journal of

Medicinal Chemistry

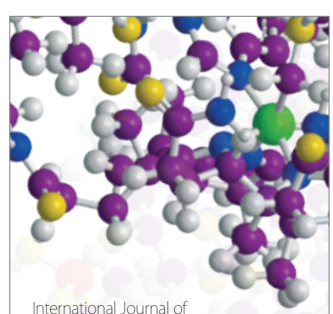

Carbohydrate Chemistry

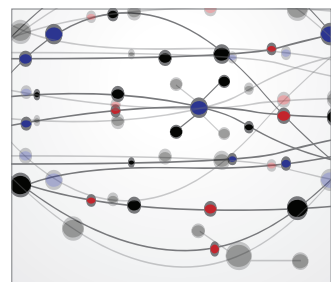

The Scientific World Journal
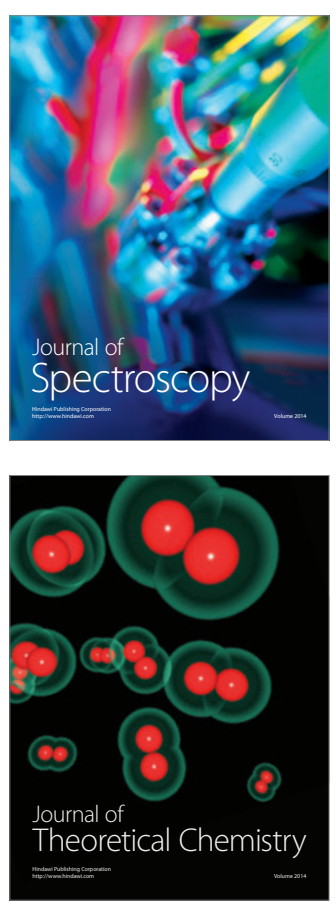
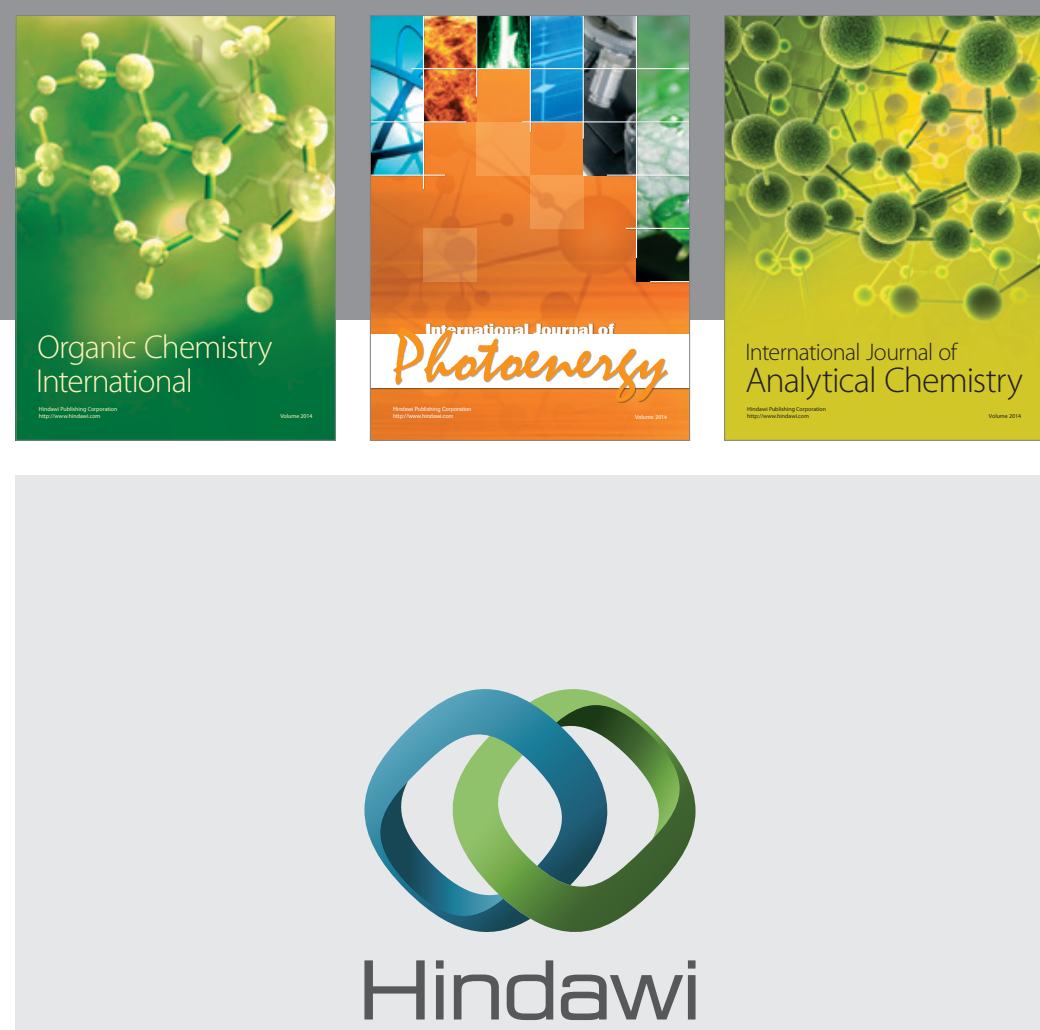

Submit your manuscripts at

http://www.hindawi.com
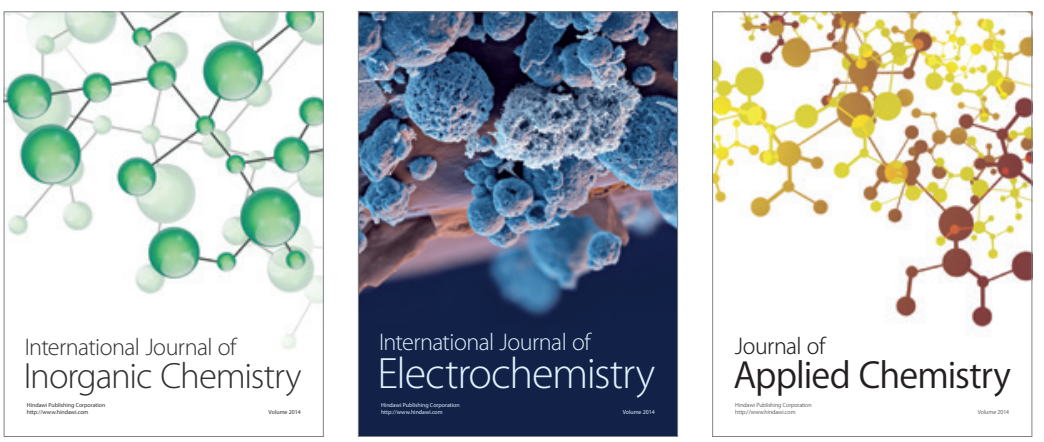

Journal of

Applied Chemistry
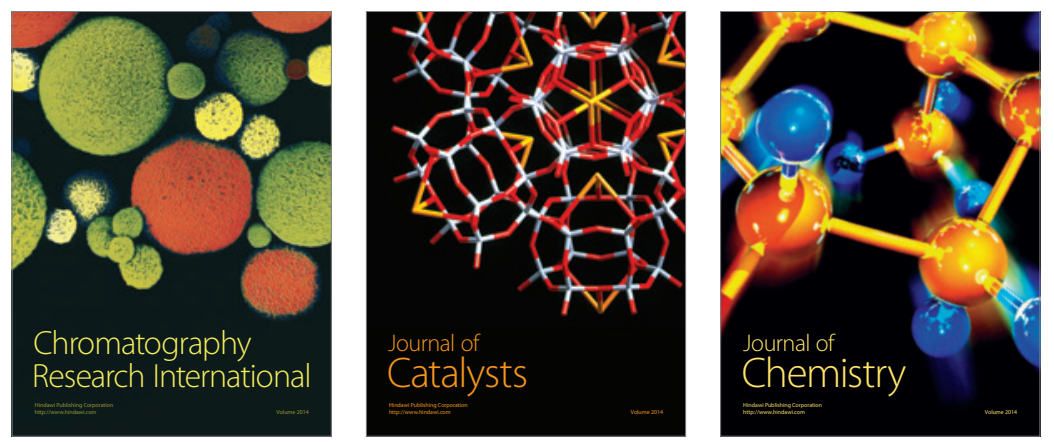
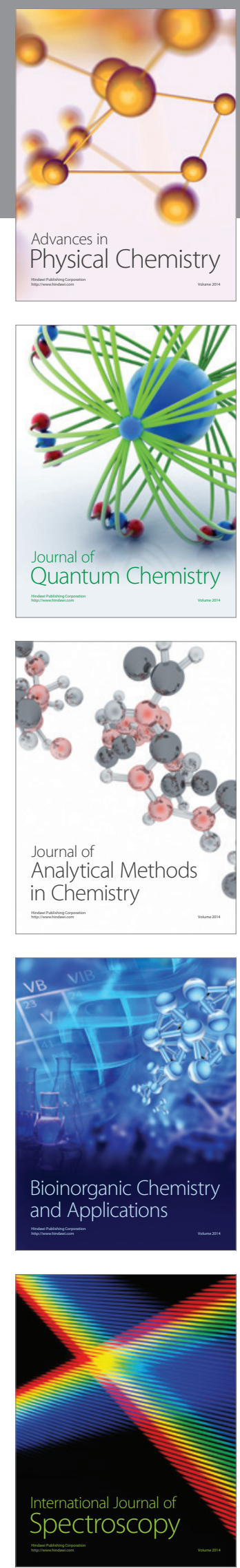